\title{
ANALYSIS THERMOGRAVIMETRIC OF TUNGSTEN COMPOSITE FOR GAMA RADIACTION SHIELDING.
}

\author{
SOUZA, A. C..$^{1 *}$; SILVA, A. C. ${ }^{3}$; ROSSI, J. L. ${ }^{2}$; CIONE, F. C. ${ }^{2}$. \\ 1 State University of Mato Grosso do Sul/ Department of Physics - CEPEMAT/UEMS, Dourados, MS, Brazil. \\ 2 Institute of Energy and Nuclear Research, IPEN - CNEN, São Paulo, SP, Brazil. \\ 3 State University of Mato Grosso do Sul/ Department of Forestry Engineering, Aquidauana, MS, Brazil.
}

*e-mail: armandocirilo@yahoo.com

\begin{abstract}
The generation of Mo-99mTc generators for hospitals requires the transport of the Mo-99m material in containers with physicochemical properties for especially the shielding of gamma radiation $[4,5]$. The application of tungsten alloys has been developed with the objective of minimizing the effects of radiation, being used in the manufacture of devices for the transport of radioactive material, considering its properties of specific mass $(60 \%$ dense than lead), resistance corrosion, excellent absorption of high energy radiation and high mechanical strength $[16,17]$. The kraft lignin, a natural polymer obtained from the Kraft process of cellulosic pulp extraction, considered a residue of the cellulosic industry, can be used as a high adhesive material. The objective of this work was to perform the Thermogravimetric (TG), Differential Exploration Calorimetry (DSC) and X-ray diffraction (XRD) analyses of a new composite of tungsten and kraft lignin. The results showed the thermal and crystallographic properties of the composite, which could contribute to obtain a new material with ability to attenuate gamma radiation.
\end{abstract}

Keywords: Tungsten; Composite; Thermogravimetric.

\section{Resumo}

A fabricação dos geradores de Mo- ${ }^{99 \mathrm{~m}} \mathrm{Tc}$ para os hospitais, requer a necessidade do transporte do insumo Mo-99m em recipientes com propriedades físico-químicas para a blindagem da radiação gama [4, 5]. A aplicação de ligas de tungstênio vem sendo desenvolvidas com o objetivo de minimizar os efeitos da radiação, sendo desta forma utilizada na fabricação de dispositivos para transporte de material radioativo, considerando suas propriedades de massa específica ( $60 \%$ mais denso que o chumbo), resistência à corrosão, excelente absorção de radiação de alta energia e de alta resistência mecânica [16,17]. A lignina kraft, polímero natural obtido a partir do processo kraft de extração de polpa celulósica, considerado resíduo da indústria celulósica, podendo ser utilizada como um material com alta capacidade adesiva. $\mathrm{O}$ objetivo deste trabalho foi realizar as análises Termogravimétricas (TG), Calorimetria Exploratória Diferencial (DSC) e Difração de Raios-X (XRD) de um novo compósito de tungstênio e lignina kraft. Os resultados mostraram as propriedades térmicas e cristalográficas do compósito, que poderão contribuir na obtenção de um novo material com capacidade de atenuação da radiação gama. 


\section{Introduction}

The Brazilian government initiated the construction of a multipurpose reactor (RMB) to have self-sufficiency of the radioactive drugs and to foment the research in the nuclear area. Part of the project is concerned with the development of specialized equipment for the transportation and containment of radioactive substances [1].

The electronic structure of tungsten makes it one of the main materials used in X-ray targets and for shielding high-energy radiation (as in the radiopharmaceutical industry to contain radioactive samples). Tungsten powder was used as a filler in composite polymer matrix materials, which are used as non-toxic substitutes for lead in antiradiation shields [2].

Lignin is a natural polymer of extremely complex phenotypic nature, heterogeneous and threedimensional, with a high carbon content, found in all plants, being the second most abundant natural macromolecule after cellulose, excellent adhesive property [3].

In this work will be presented analysis of thermogravimetric (TG), differential scanning calorimetry (DSC) and X-ray diffraction (XRD) of a new composite of tungsten and kraft lignin [4].

\section{Materials and Methods}

\section{Lignin Kraft}

The lignin used was obtained from the black liquor from the kraft extraction process of cellulosic pulp. Basically, for the removal and isolation of the kraft lignin extracted from the black liquor, carbonation was carried out followed by acidification at $\mathrm{pH} 2$. In the first, the carbonic gas was bubbled into the hot black liquor, recovering between 75 and $80 \%$ of the lignin by filtration. In the second step, the filtrate was treated with sulfuric acid, recovering approximately $10 \%$ powdered kraft lignin.

\section{Metal}

The metal samples that were used as precursors were the powdered tungsten, which after being submitted to different steps of granulometry using different sieve numbers, with the granulometry in the order of $250 \mu \mathrm{m}$, in order to obtain the formation of the composite with higher degree of homogeneity.

\section{Composite}

For the preparation of the samples, the precursors were weighed according to the desired mass ratio for the composite composition, in the stoichiometric proportion of masses from 5\% lignin to $95 \%$ tungsten. Subsequently, the mixture was homogenized and subjected to pressing, in a press with capacity of 15 tons, obtaining samples of $1.2 \mathrm{~cm}$ in diameter and 0.8 $\mathrm{cm}$ in height.

\section{Thermogravimetric analysis}

After the processing, TG and DSC thermogravimetric analysis of the pure kraft lignin powder of the W5\%Lig homogenized powder were performed using platinum and alumina crucibles. Measurements in TG were performed with a heating rate of $10^{0} \mathrm{C} \cdot \mathrm{min}^{-1}$ to a temperature of $1100^{\circ} \mathrm{C}$ under inert atmosphere; Measurements in the DSC were performed with a heating rate of $10^{\circ} \mathrm{C} \cdot \mathrm{min}^{-1}$ to a temperature of $500^{\circ} \mathrm{C}$ under inert atmosphere.

\section{X-ray diffractometry}

To verify possible structural changes and to determine the crystallographic parameters of the $\mathrm{W}$ and of the composite, X-ray diffraction (XRD) measurements were performed. The resulting diffraction were analyzed with the aid of the APD / PHILIPS software mineral database and through a literary consultation in the Hanawalt and Fink methods in the comparison of results with standards developed by the International Center for Diffraction Data (ICDD) Joint Committee for Powder Diffraction System (JCPDS).

\section{Results and Discussion}

The Figure 1, we observed that tungsten has a stability up to $3500 \mathrm{C}$ and from this temperature the mass increase is linear up to $1100^{\circ} \mathrm{C}$, in the case of kraft ligin the mass loss is exponential.

The Figure 2, the composite without heat treatment, where we can observe a continuous loss in weight up to $200^{\circ} \mathrm{C}$ being attributed to loss of surface water and the interstitial composite and then to $400^{\circ} \mathrm{C}$, we have an increase in higher mass loss attributed to degradation of organic compounds in Kraft lignin, and from the 
$400^{\circ} \mathrm{C}$ we observed an increase in mass due to oxidation of tungsten present in the compound.

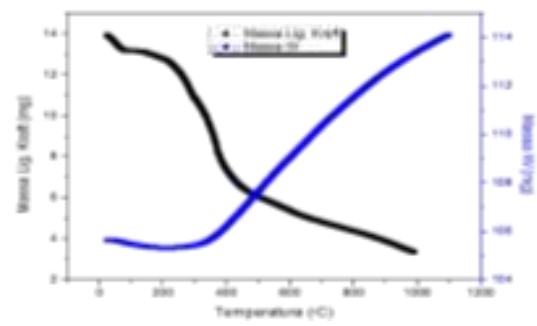

Figure 1: TG of precursors.

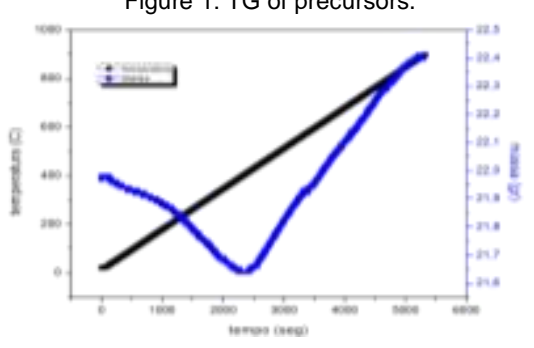

Figure 2: TG of W5\%Lig powder.

The Figure 3, represent of the differential calorimetry energy of precursor tungsten and lignin. On the lignin is possible observed one phase transition endothermic attributed the lost of water in at temperature of $100^{\circ} \mathrm{C}$ and one phase transition exothermic attributed the thermal degradation of carbon released by phenolic rings in at $400^{\circ} \mathrm{C}$. On the $\mathrm{W}$ is possible observed two phase's transition exothermic associated with absorption of oxygen.

The Figure 4, represents the differential calorimetry energy of the composite W5\%Lig without heat treatment, showing the stability of the composite until $300^{\circ} \mathrm{C}$, when start the oxidation process of $\mathrm{W}$, inhibiting the reactions of lignin due to the high concentration of $\mathrm{W}$ in the composite.
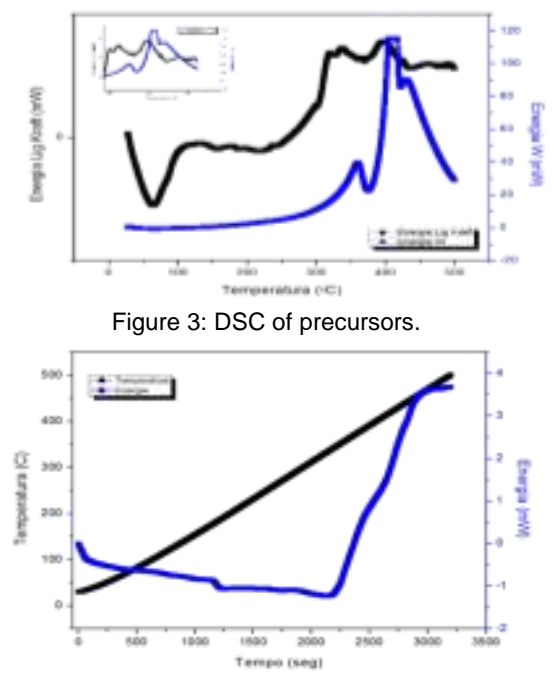

Figure 4: DSC of W5\%Lig powder.
The Figure 5, represents the spectrum of refinement of $x$-ray diffraction with the aid of the mineral database and through literary Hanawalt methods query and Fink in the comparison of results with the patterns produced by the Joint Committee for Powder Diffraction System (JCPDS). We observed the lines of the phase decomposition $\mathrm{W}$, in order to allow a homogeneity during processing of the composite, without oxides contamination.

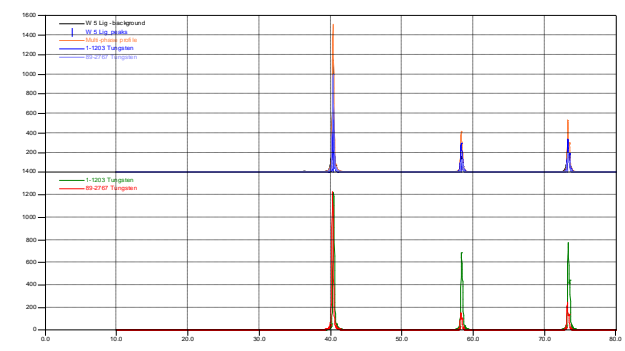

Figure 5: X-ray diffraction and the identification of phases of the spectrum of W.

\section{Conclusion}

The kraft lignin samples showed a good homogeneity in composite mix W5\%Lig, considering that lignin is a substance organic. The TG analyses showed that the lignin presents a thermal degradation exponential attributing a degradation of phenolic composite, while the $\mathrm{W}$ presents an oxidation process from $300^{\circ} \mathrm{C}$. The samples of composite shows that has a reduction on the oxidation process of $\mathrm{W}$ how precursor. The DSC analyses showed that the endothermic and exothermic processes are inhibited by presence lignin, when in the form composite. The results showed that the kraft lignin represents an excellent alternative to form the tungsten composite.

\section{References}

[1] CHUNA, Y. B. et. al. Journal of Nuclear Materials, 265, 28-37, 1999.

[2] CHEN, L. C., MA, S. H., Jornal of Alloys and Compounds, ELSEVIER, 2017.

[3] PAOLA, G. Journal of Analytical and Applied Pyrolysis 100, 213-222, 2013.

[4] KIRAKOSYAN, H.V. et. al. J. Therm. Anal. Calorim. 123, 35-41, 2016. 